\title{
Development of an integrated approach to assessing the sanitary quality of feed for fur-bearing animals
}

\author{
Sergei V. Beketov*, Alexander V. Kozlov, Oleg V. Gorbunov, and Natalia A. Golovacheva \\ K.G. Razumovsky Moscow State University of Technologies and Management (the First Cossack University), 109004 Moscow, Russia
}

\begin{abstract}
In the article a brief description of new analytical methods for the indirect determination of bacterial contamination of the finished feed mixture and dry feed for fur-bearing animals by the level of adenosine triphosphate (ATP) and ammonia are provided. The prospects for their use in comparison with the method of analysis of total volatile nitrogen are assessed.
\end{abstract}

\section{Introduction}

It is well known that certain breeding and selection activities carried out by workers on a livestock farm form an appropriate level of productivity of a particular breed or intra-breed type of farm animals.

In particular, in animal breeding in sables (the black sable breed) by selecting parents who differ in the degree of darkening of the hair color, it is possible to significantly increase the yield of puppies to the female of the main herd [1].

Another example is the breeding of a voile arctic fox, in which the secondary sex ratio (the proportion of males at birth) is genetically determined and inherited from the paternal line [2]. This allows artificially forming a group of animals that give predominantly males in the offspring, which, taking into account sexual dimorphism in body size, increases the profitability of the production of skins in this type of fur-bearing animals.

At the same time, the growth of young animals, the state of animal health, the appearance of defects on the skin, and the reproductive ability of females are largely determined by the quality of the feed.

In this connection, along with fodder supply, expressed in the availability and balance of essential nutrients, an important task of farming is a quick, effective and accessible assessment of the state of sanitary and chemical quality of food.

Fodder value and safety of forages for fur-bearing animals in many respects depends on degree of their bacterial contamination and as a consequence of availability of products of disintegration of protein. Under the action of proteolytic enzymes of microorganisms, protein molecules break down to polypeptides, tri-and dipeptides, which are cleaved to amino acids, followed by the formation of various intermediate and final products of their decay [7].

First of all, it concerns the determination of the level of total volatile nitrogen as an indicator of spoilage of feed protein. However, the currently existing methods for determining TVN [4, 5] in feed for fur-bearing animals are rather laborious, lengthy and have limitations in use.

In this connection, the purpose of our research was the development of new methods for assessing the sanitary quality of the finished feed mixture and dry feed for fur-bearing animals.

\section{Materials and methods}

The objects of study were 36 samples of finished feed mixture for fur-bearing animals obtained from 3 types of fur farming in the Moscow region and one of the Tver region, as well as 76 samples of dry feed of animal origin, used in fur farming (protein concentrate, meat and bone meal, fish meal, enzymatically hydrolyzed feather meal, extruded meal, blood meal).

The sanitary-chemical quality of feed for fur animals determines the content of total volatile nitrogen $[4,5]$, ammonia [6], as well as by measuring the ATP level using a portable luminometer Clean Trace3M. Statistical data processing was performed using Microsoft Excel and STATISTICA.

\section{Results}

The amount of total volatile nitrogen (TVN) is a reflection of the proteolytic microbial processes occurring in the feed during transportation and storage.

In addition to total volatile nitrogen, an indirect characteristic of the degree of bacterial contamination can be the definition of adenosine triphosphate (ATP) in the diet. The concentration of ATP will be directly proportional to the intensity of the luminescent glow recorded by the luminometer and expressed in relative light units (RLU) or 1 femtomol (10-15 mol) ATP=1 RLU.

This greatly increases the measurement speed, because using a luminometer after a few seconds; it is

* Corresponding author: mirvar@rambler.ru 
possible to get the results. During the development of a rapid criterion for assessing the sanitary-chemical quality of the finished feed mixtures for fur-bearing animals, a series of test tests were conducted, during which the quantitative values of ATP are compared with the analysis data on the level of total volatile nitrogen.

When conducting model experiments, different degrees of spoilage (microbiological contamination) of the feed are artificially called, placed in a Petri dish by samples of the feed mixture in a exsiccator for a day, day and a half, two and three days at $\mathrm{t}=28-30{ }^{\circ} \mathrm{C}$.

Moreover, the most objective data were obtained using pre-filtered aqueous extracts of the feed mixture for furbearing animals. As a result, according to the test results, a linear relationship was established between the content of total volatile nitrogen and the luminescence intensity in samples of the finished feed mixture of various degrees of microbiological contamination (Fig. 1).

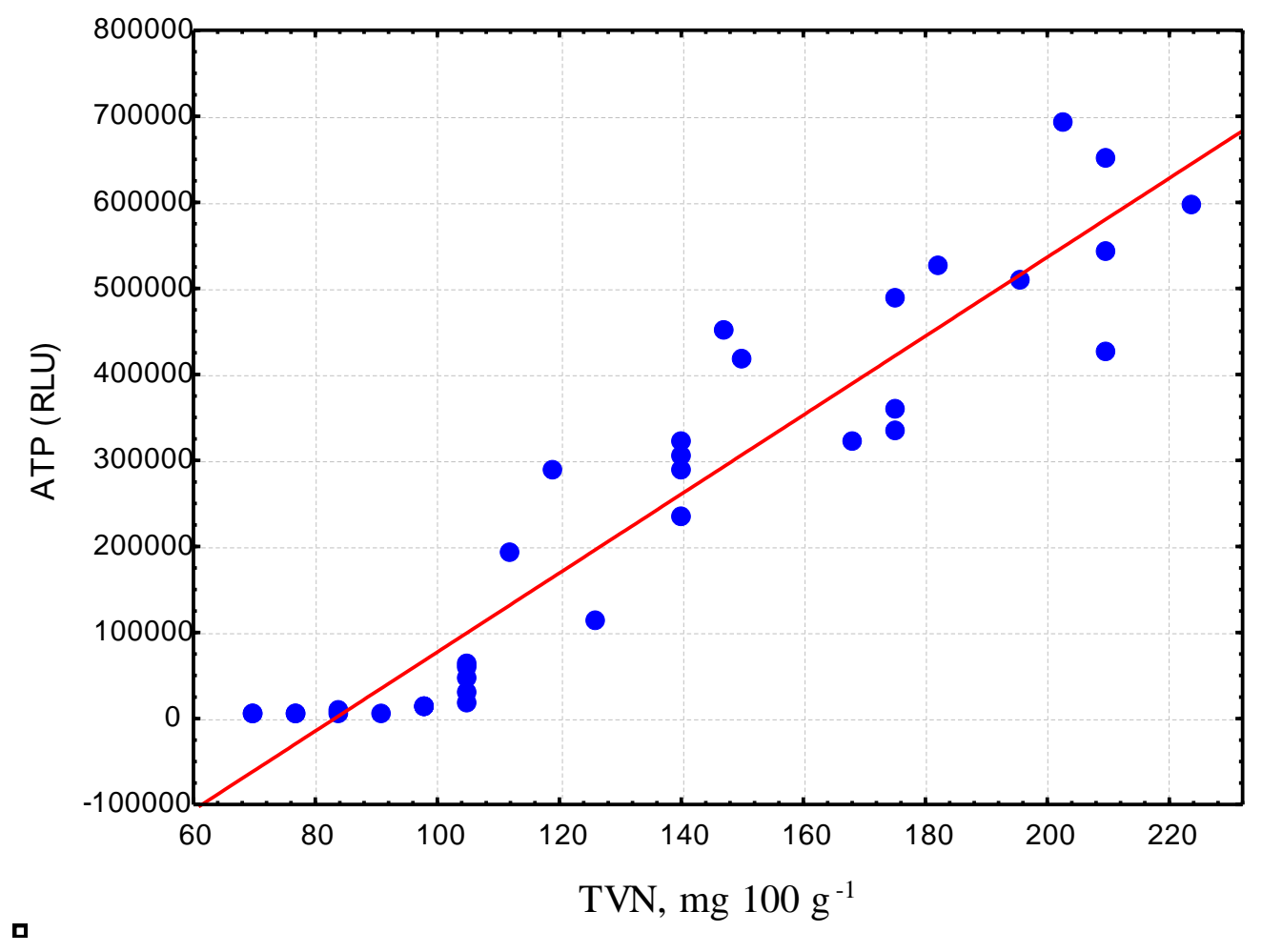

Fig. 1. Graph of the regression equation $y=-3,8169 \cdot 105+4589,5882 x$, reflecting the relationship between the TVN level (mg 100 $\mathrm{g}-1)$ and ATP (RLU) according to the results of analyzes of samples of the finished feed mixture for fur-bearing animals.

At the same time, the calculated values of the coefficients of determination R2 $=0.8922$ and correlations $\mathrm{r}=0.9446(\mathrm{p}<0.001)$ indicate a fairly close relationship between the indicators under consideration, which allows constructing a comparable measurement scale for two different methodological approaches (Table 1).

From results of the experiments an extremely simple and affordable methodological approach for the luminometric determination of the sanitary quality of the finished feed mixture was proposed.

According to the proposed methodology for luminometric analysis, a grooved tip of the probe of the test system is carefully immersed in a glass cup with a filtered aqueous extract of a sample of feed. After that, the probe with the studied material is inserted back into the test tube with the reagent and within 25 with a pendulum-like motion, the test system is activated.

Then put it in a pre-turned on device and analyze the sample. Comparing the results with the recommended maximum allowable concentrations, decide on the future use of feed.

However for dry feeds, it was not possible to establish a linear relationship between the total ATP level and total volatile nitrogen (the correlation coefficient $r=0.22 ; p>0.05)$. The reason for this discrepancy may be that, in the preparation of dry feed, the feedstock is subjected to high thermal treatment, causing the death of vegetative and part spore-forming microorganisms. While the measured level of ATP directly correlates with bacterial contamination.

Table 1. Scale of comparable measurements of ATP and TVN

\begin{tabular}{|c|c|c|}
\hline \multirow{2}{*}{ Feed } & \multicolumn{2}{|c|}{ Measurement indicators } \\
\cline { 2 - 3 } & ATP (RLU) & TVN, mg $100 \mathrm{~g}^{-1}$ \\
\hline \multirow{4}{*}{$\begin{array}{c}\text { Finished feed } \\
\text { mixture }\end{array}$} & $\begin{array}{c}\text { Not more than } \\
4000\end{array}$ & Not more than 70 \\
\cline { 2 - 3 } & $4000-6000$ & $70-80$ \\
\cline { 2 - 3 } & $6000-10000$ & $80-90$ \\
\cline { 2 - 3 } & $10000-16000$ & $90-100$ \\
\cline { 2 - 3 } & $16000-290000$ & $100-120$ \\
\cline { 2 - 3 } & $290000-320000$ & $120-140$ \\
\cline { 2 - 3 } & $320000-690000$ & $140-200$ \\
\hline
\end{tabular}

In addition, due to low moisture content and the use of preservatives in dry feed of animal origin, the reproduction rate and proteolytic activity of bacteria and 
fungi is slowed down, as a result, the ATP values obtained are insignificant and are within the background.

In order to solve this problem, we used the method of determining ammonia in an aqueous extract, which was found in the NPO ZAO "Crismas + » for the analysis of meat and by-products [6].

The essence of this approach lies in the fact that at the level of limit values ammonia with the help of Nessler's reagent $\left(\mathrm{K}_{2}\left[\mathrm{HgI}_{4}\left(\mathrm{H}_{2} \mathrm{O}\right)_{2}\right]\right)$ forms mercuramide compounds, painted in orange color.

In fact, in the study of various dry feeds, with the exception of the critical excess of harmful decay products of protein (orange color), the color range changed depending on the type of feed and the concentration of ammonia (Tables 2, 3; Fig. 2, 3).

According to the data presented in the Table 1, as a protein concentrate, meat and bone meal and fish meal have similar color changes in the following TVN value ranges: $70-105 \mathrm{mg} 100 \mathrm{~g}^{-1}$ - light green; $105-175 \mathrm{mg} 100$ $\mathrm{g}^{-1}$ - yellow-green and 175-300 mg $100 \mathrm{~g}^{-1}$ - dark green.

Table 2. Comparable measurements of the level of ammonia and TVN in the protein concentrate, meat and bone meal and fish meal

\begin{tabular}{|c|c|c|c|c|c|}
\hline \multirow{2}{*}{ Feed type } & \multirow{2}{*}{$\begin{array}{c}\text { Measurement } \\
\text { parameters }\end{array}$} & \multicolumn{4}{|c|}{ Ammonia and TVN level } \\
\hline & & minor & \multicolumn{2}{|c|}{ medium } & $\begin{array}{l}\text { maximum } \\
\text { allowable }\end{array}$ \\
\hline \multirow{2}{*}{$\begin{array}{l}\text { Protein } \\
\text { conce } \\
\text { ntrate }\end{array}$} & $\begin{array}{c}\text { ammonia } \\
\text { (color) }\end{array}$ & $\begin{array}{l}\text { light } \\
\text { green }\end{array}$ & $\begin{array}{c}\text { yellow- } \\
\text { green }\end{array}$ & $\begin{array}{l}\text { dark } \\
\text { green }\end{array}$ & \multirow{2}{*}{-} \\
\hline & $\begin{array}{c}\text { TVN, mg } \\
100 \mathrm{~g}^{-1} \\
\end{array}$ & $70-105$ & $105-175$ & $175-300$ & \\
\hline \multirow{2}{*}{$\begin{array}{c}\text { Meat and } \\
\text { bone } \\
\text { meal }\end{array}$} & $\begin{array}{c}\text { ammonia } \\
\text { (color) }\end{array}$ & $\begin{array}{l}\text { light } \\
\text { green }\end{array}$ & $\begin{array}{c}\text { yellow- } \\
\text { green }\end{array}$ & $\begin{array}{l}\text { dark } \\
\text { green }\end{array}$ & \multirow{2}{*}{-} \\
\hline & $\begin{array}{l}\text { TVN, mg } \\
100 \mathrm{~g}^{-1}\end{array}$ & $70-105$ & $105-175$ & $175-300$ & \\
\hline \multirow{2}{*}{ Fish meal } & $\begin{array}{c}\text { ammonia } \\
\text { (color) }\end{array}$ & \multirow{2}{*}{ - } & $\begin{array}{c}\text { yellow- } \\
\text { green }\end{array}$ & $\begin{array}{l}\text { dark } \\
\text { green }\end{array}$ & orange \\
\hline & $\begin{array}{c}\text { TVN, mg } \\
100 \mathrm{~g}^{-1}\end{array}$ & & $105-175$ & $175-300$ & $>300$ \\
\hline
\end{tabular}

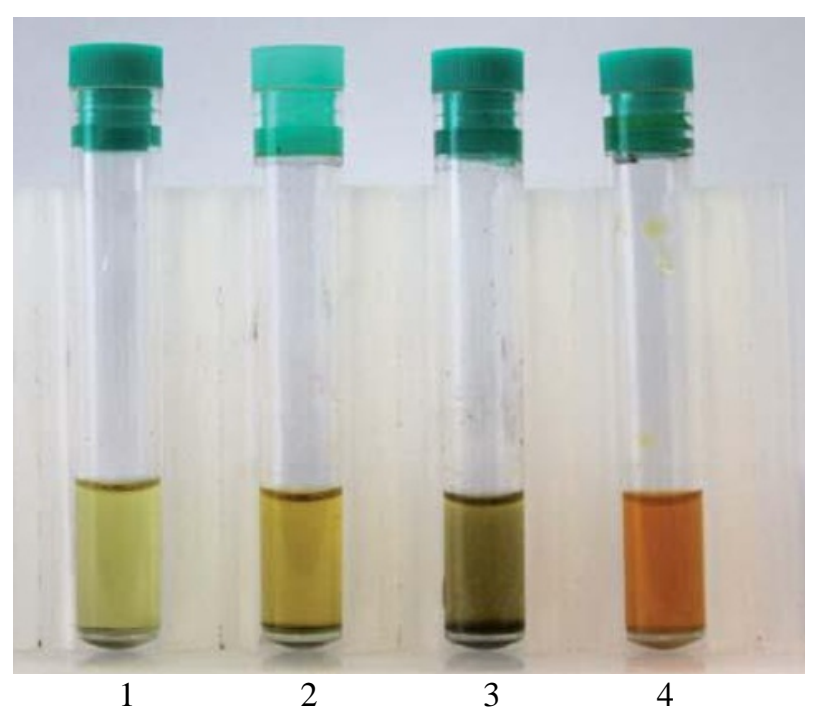

Fig. 2. Color reaction to the presence of ammonia in high protein concentrate, meat and bone meal and fish meal, depending on the level of total volatile nitrogen in these samples (mg $\left.100 \mathrm{~g}^{-1}\right)$ : 1 - 70-105; 2 - 105-175; 3 - 175-300; 4 - more than 300
Table 3. Comparable measurements of the level of ammonia and TVN in the hydrolyzed feather meal, feather meal and blood meal

\begin{tabular}{|c|c|c|c|}
\hline \multirow{2}{*}{ Feed type } & \multirow{2}{*}{$\begin{array}{c}\text { Measurement } \\
\text { parameters }\end{array}$} & \multicolumn{2}{|c|}{$\begin{array}{c}\text { Ammonia and TVN } \\
\text { level }\end{array}$} \\
\cline { 3 - 4 } & minor & $\begin{array}{c}\text { maximum } \\
\text { allowable }\end{array}$ \\
\hline $\begin{array}{c}\text { Hydrolyzed } \\
\text { feather meal }\end{array}$ & ammonia (color) & yellow & orange \\
\cline { 2 - 4 } $\begin{array}{c}\text { Feather } \\
\text { meal }\end{array}$ & TVN, mg 100 g & $85-300$ & $>300$ \\
\cline { 2 - 4 } & ammonia (color) & yellow & orange \\
\hline \multirow{2}{*}{ Blood meal } & ammonia $100 \mathrm{~g}^{-1}$ & $85-105$ & $>130$ \\
\cline { 2 - 4 } & TVN, ${\mathrm{mg} 100 \mathrm{~g}^{-1}}^{-1}$ & yellow & orange \\
\hline
\end{tabular}

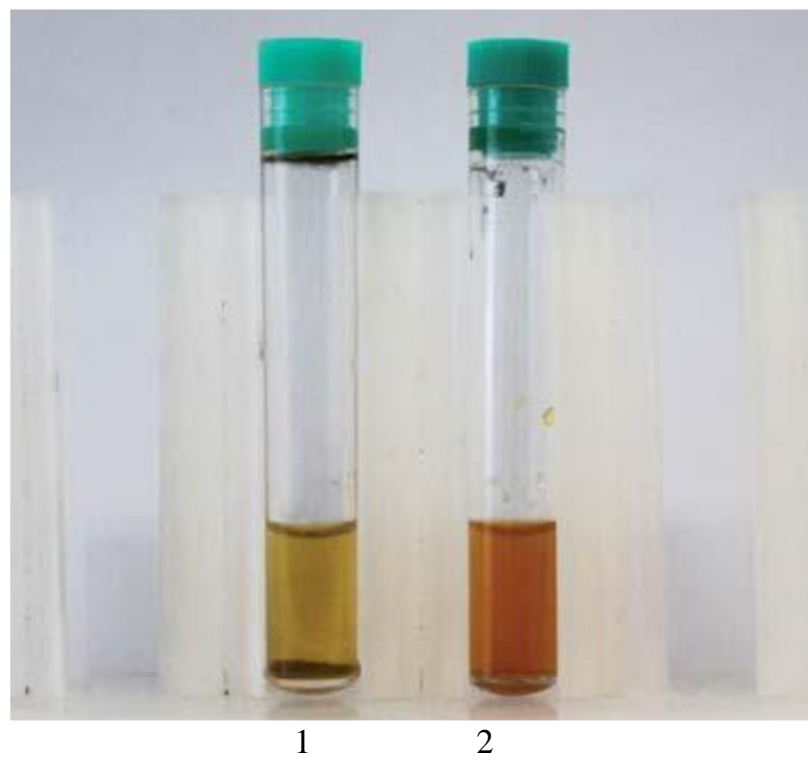

Fig. 3. Color reaction to the presence of ammonia in the feather hydrolyzate, feather meal and blood meal, depending on the

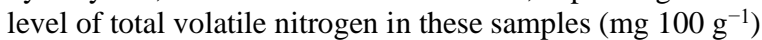
1-85-300 for hydrolyzed feather meal, 85-105 for feather meal 40-105 for blood meal; 2. - more than 300 for hydrolyzed feather meal and more than 130 for feather meal and blood meal.

For fishmeal, no samples have yet been found, the level of TVN in which falls in the range of 70-105 mg $100 \mathrm{~g}^{-1}$. Similarly, out of the total number of samples examined in protein concentrate and meat and bone meal, samples could not be detected if the level of maximum permissible TVN concentrations was exceeded.

Table 3 combines the following group of feeds (hydrothermal hydrolyzate of poultry feathers, feather and blood meal).

\section{Discussion}

In the industrial farming the feed of animal origin is mainly used: frozen, dry and canned. At the same time,

the nutritional value and preservation of feed for furbearing animals largely depends on the degree of their bacterial contamination and, as a consequence, the presence of intermediate and final protein breakdown products, which cause various disturbances in the physiological functions of fur-bearing animals (affect reproduction, inhibit appetite, increase blood pressure, 
cause liver dystrophy and death) [7], which generally leads to a decrease in the general economic indicators of fur farming enterprises.

The specifics of fur farms in the Russian Federation and the CIS countries, is caused by the fact that preparation of a forage mixture for fur-bearing animals is carried out on own forage kitchen. In the composition of the rations in large numbers the perishable raw food of animal origin (non-food fish, meat and fish wastes) is used.

In this regard, inevitably there is a need to quickly control the quality characteristics of the source and feed prepared from it.

However, currently the chemical method of determining the quality of feed by the level of total volatile nitrogen (TVN) [8-10], despite the apparent simplicity, is rather long and laborious.

Moreover, the full implementation of this method in fur farms is associated with certain organizational difficulties: the presence of its own laboratory and qualified personnel.

It is important to note that the use of our proposed new methods for assessing the sanitary quality of feed in comparison with TVN significantly reduces the time taken to test a single sample from 1,5-2,5 hours to 20 minutes. In addition, in the case of the luminometric method does not require reagents at all (ready-made swabs are used) and only one chemical reagent is needed when determining ammonia in the feed.

The method for determining the AAA, depending on its modification, requires from 10 [4] to 2 [5] chemical reagents, which increases the cost of feed analysis. In addition, the proposed new methods of determination of the sanitary quality of feed are quite simple and are available in the performance of any specialist fur farms and can be used comprehensively, respectively, for wet feed (finished feed mixture) - luminometric method and for dry feed - method for determining ammonia.

\section{Conclusion}

For an objective judgment on proteolytic microbial processes occurring in feed, an indicator of total volatile nitrogen is traditionally used.

However, the determination of the sanitary-chemical quality of the feed by the level of TVN is quite long and laborious. In this regard, chemoluminescence can be considered as an alternative method, the intensity of the reaction of which is determined by the level of adenosine triphosphate, which increases significantly depending on the quantitative growth of microbiota involved in the proteolysis of feed of animal origin.

It is enough to say that this methodological approach is extremely popular, as it allows even an untrained user verifying the sanitary condition of the feed in a matter of minutes. While the petrifilm plate method or traditional microbiological analysis for the presence in the samples of fungi and bacteria takes from 1 to 5 days.

However, on dry feeds, the use of luminometric analysis was not applicable.
The solution to this problem became possible by using the method of analysis of ammonia (color reaction). In addition to the specified methodology with an appropriate scale of quantitative values, the proposed approach, in contrast to the determination of total volatile nitrogen, not only significantly accelerates and reduces the cost of analysis, but also allows obtaining more objective information about the sanitary-chemical state of dry feed.

Thus, the possibility of using the luminometric measurement of the amount of ATP is limited by the group of wet feed of animal origin, while dry feed as a substrate is characterized by an extremely low degree of microbial activity, which prevents the adequate application of this methodological approach.

In this case, as an alternative, the most optimal is the use of ammonia analysis method (color reaction).

\section{References}

1. C.V. Beketov, I.E. Chernova, Yu.I. Rozhkov, L.V. Toporova, K.S. Karpov, Dimming of color as a marker of decreased reproductive ability of female sables (Martes zibellina) and minks (Neovison vison) Ecological genetics (in press) DOI.org/10.17816/ecogen $173 \% 25$ p.

2. S.V. Beketov, S.N. Kashtanov, Effect of hereditary characteristics of male blue foxes (Alopex lagopus L.) on the sex ratio of their offsprings Russ. J. of Genetics 41(3), 333-336 (2005)

3. S. Ariyawansa, The evaluation of functional properties of fish meal 25 (UNU-Fisheries Training Programme. Final Project, Reykjavik, 2000)

4. E.A. Petuhova, R.F. Bessarabova, L.D Haleneva, O.A. Antonova, Zootechnical analysis of feeding stuffs (Kolos, Moscow, 1981)

5. GOST R 55479-2013 Meat and meat products. Methods for the determination of amino ammonia nitrogen (FGUP "Standartinform", Moscow, 2014)

6. Test Food Sanitary Guide (Krismas+, St. Petersburg, 2014)

7. V.S. Slugin, Diseases of carnivorous fur-bearing animals and their etiological connection with the pathology of other animals and humans (Kirov region typography, Kirov, 2004)

8. I. Pölönen, Silage for Fur Animals. Preservation Efficiency of formic acid and benzoic acid in the ensiling of slaughterhouse by-products and their subsequent metabolism in farmed fur animals, $\mathrm{PhD}$ dissertation thesis (Dept. of Animal Science, University of Helsinki, Helsinki, 2000)

9. C. Tantikitti, S., Kuprasert, R. Laohabanjong et al., Fish meal quality evaluated by chemical analysis and feed microscopy techniques Songklanakarin J. Sci. Technol. 27(1), 25-44 (2005)

10. H. Herborg, R. Leif, Njaa, Total volatile nitrogen A quality criterion for fish silage? Aquaculture 79(1-4), 311-316 (1989) 